\title{
Ayak bileği ostekondral lezyonları
}

\author{
Osteochondral lesions of the ankle
}

\author{
Ramazan Akmeşe, Mehmet Batu Ertan
}

Ankara Üniversitesi Tıp Fakültesi, İbni Sina Hastanesi, Ortopedi ve Travmatoloji Anabilim Dalı, Ankara

\begin{abstract}
Talus osteokondral lezyonları tedavisi zor ve karmaşık bir problem olup aktivite artışıyla ağrı semptomları yaratır. Tanısında, takibinde ve sınıflandırılmasında manyetik rezonans görüntüleme en sık kullanılan yöntemdir. 1,5 cm2'den büyük lezyonlarda, korunmasız lezyonlar olarak isimlendirilen talus omuz lezyonlarında ve subkondral kistik yapı içeren lezyonlarda prognoz kötüdür. Tedavisi semptomatik hastalarla sınırlı tutulmalıdır. Konservatif tedavinin etkinliği kısıtlı olup sadece semptomatik bir tedavidir. Aktivite beklentisi yüksek ve semptomları belirgin olan hastalarda cerrahi tedaviler ön plandadır. Cerrahi tedavi ile hiyalin benzeri kıkırdak yapının oluşumu amaçlanmaktadır. $1,5 \mathrm{~cm}^{2}$ 'den küçük lezyonlarda mikrokırık; daha büyük lezyonlar ve kistik lezyonlarda ise mozaikplasti en sık kullanılan tedavi uygulamalarıdır. Mikrokırığı desteklemek için hücresiz çatı (skaffold) implantları, konsantre kemik iliği aspiratı uygulamaları, hiyaluronik asit ve PRP uygulamaları yapılabilmektedir. $3 \mathrm{~cm}^{2}$ 'den büyük lezyonlarda ve revizyon cerrahilerde ise osteokondral allogreft transplantasyonu, otolog kondrosit implantasyonu ve yüzey artroplastisi tercih edilen cerrahi prosedürlerdir.
\end{abstract}

Anahtar sözcükler: ayak bileği; hiyalin benzeri kıkırdak; mikrokırık; mozaikplasti; talus osteokondral lezyon
Talus osteochondral lesions have difficult and complex treatment procedures, and give pain as symptoms with activity. Magnetic resonance imaging is the preferred way of diagnosis, follow-up, and classification of the lesions. The prognosis is bad in the lesions bigger than $1.5 \mathrm{~cm} 2$, uncontained lesions in talus shoulder, and the lesions with subchondral cysts. The treatment must be limited to symptomatic patients. The effect of conservative treatment is limited and only symptomatic. Surgical treatments are preferred for active patients and those with severe symptoms. The aim of surgical treatment is to obtain hyaline-like cartilage. The mainly used surgical procedures are microfracture in lesions smaller than $1.5 \mathrm{~cm}^{2}$, and mosaicplasty in bigger ones. In adjunctive treatment of microfracture cell-free scaffolds, concentrated bone marrow aspirate, hyaluronic acid, and platelet-rich plasma are used. In the lesions bigger than $3 \mathrm{~cm}^{2}$ and in revision surgery, osteochondral allograft transplantation, autologous chondrocyte implantation, and resurfacing arthroplasty are the preferred surgical procedures.

Key words: ankle; hyaline-like cartilage; microfracture; mosaicplasty; talus osteochondral lesion

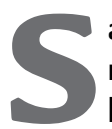
adece ABD'de günde 27.000 ayak bileği burkulmaktadır. ${ }^{[1]}$ Akut ayak bileği burkulması ya da kırıklarının yarısında kondral ya da osteokondral lezyon (OKL) görülebilmektedir. ${ }^{[2-6]}$ OKL, kıkırdağın avasküler yapısı iyileşmesinde problemler yarattığı gibi, zamanla lezyon boyutunda büyümeye yol açar ve dejeneratif artroza neden olur. ${ }^{[7,8]}$

Geniş bir literatür taraması ile oluşturulan bir çalışma, ortopedistler için problemli ve zor olgular olarak kabul edilen talus OKL hakkında genel bilgiler ve özellikle son yıllarda gelişme gösteren farklı tedavi yaklaşımlarını içermektedir. ${ }^{[9]}$

\section{KLINIK BULGULAR}

OKL çoğu zaman travmatik nedene bağlı iken, travmatik olmayanların oranı \%24'tür. ${ }^{[10,11]}$ Hastaların \%70'ini erkekler oluşturur ve en sık görülen yaş aralığı 20-30'dur. ${ }^{[12]}$ En belirgin şikayet, diğer ayak bileği problemlerinde olduğu gibi aktiviteyle artış gösteren ağrı, hareket kısıtlılığı ve şişliktir. Bu durum, tanıda klinik bulgulardan ziyade görüntüleme yöntemlerinin kullanımını baskın kılmıştır. ${ }^{[13,14]}$ Semptomlar fiziksel aktiviteyle artış gösterirken, kronik ayak bileği instabilitesinin talus OKL için bir risk faktörü olduğu unutulmamalıdır. Bu nedenle, bu hastalara instabilite muayenesi mutlaka

- İletişim adresi: Doç. Dr. Ramazan Akmeşe, Ankara Üniversitesi Tıp Fakültesi, İbni Sina Hastanesi, Akademik Yerleşke K-Blok 1. Kat, Ortopedi ve Travmatoloji Anabilim Dalı, Hacettepe Mahallesi, Samanpazarı, Altındağ, Ankara, Türkiye Tel: 0535 - 9784495 e-posta: rakmese@yahoo.com

- Geliș tarihi: 1 Ocak2018 Kabul tarihi: 1 Ocak 2018 
yapılmalıdır. ${ }^{[15]}$ Ayak bileğinde takılma ve kilitlenme, nadiren görülen semptomlardır. Fizik muayene ve semptomatik bulgular, lezyonun lokasyonuna göre de farklılık gösterebilir. En belirgin fizik muayene bulguları, ayak bileği fleksiyon ve ekstansiyonu ile belirginleşen tibiotalar eklem çevresideki hassasiyettir. ${ }^{[16]}$

\section{PROGNOSTIK FAKTÖRLER}

\section{OKL Lokasyonu}

Berndt ve Hardy, talus OKL'nin en sık yerleşim yerinin posteromediyal (\%57) ve anterolateral (\%43) olduğunu bildirmişlerdir. ${ }^{[3]}$ Elias ve ark. ise 428 hastalık serilerinde, mediyal talar lezyonların daha sık görüldüğünü ve lateral lezyonlara göre daha büyük boyutlarda oluştuğunu vurgulamışlardır. Yapılan bu çalışmada, "9-zon sistemi" kullanılarak talus eklem yüzeyi dokuz alana ayrılmış ve lezyon lokasyonları belirlenmiştir. Lezyonun en sık yerleşim yerinin santromediyal zonda (\%53), takiben santrolateral zonda $(\% 25,7)$; en az ise posteromediyal $(\% 6,8)$ ve anterolateral zonda $(\% 2,3)$ olduğu bildirilmiştir. ${ }^{16]}$ Lezyon lokasyonunun prognozda oynadığı rol tartışma konusudur. Chuckpaiwong ve Schimmer'in yaptıkları farklı çalışmalara göre, mediyal yerleşimli lezyonlarda tedaviye yanıt lateral yerleşimlilere oranla daha iyidir. ${ }^{[17]}$ Başka çalışmalarda ise lezyonun yerleşim yerinin tedavi sonucuna bir etkisinin olmadığı bildirilmiştir. ${ }^{[18]}$ Kesin olan kanaat şu ki, yuvarlak yüzeylerde yer alan lezyonlar yani talus omuz lezyonları "korunmasız lezyonlar" olarak adlandırılır; çünkü onarılan sahada oluşacak yeni dokunun tutunması için stabilizasyonu sağlayacak yapı yetersizdir. Bu sahadaki lezyonlar en kötü prognoza sahiptir. ${ }^{[17,19-22]}$

\section{OKL Boyutu}

Tüm yazarlar tarafindan oluşan konsensusa göre, talus OKL'de lezyon boyutu büyüdükçe prognoz olumsuz etkilenmektedir ve tedavisi daha komplike hale gelmektedir. Prognoz 1,5 cm${ }^{2}$ 'den küçük lezyonlarda daha iyi olup, bu boyuttaki semptomatik lezyonlarda debridman ve drilleme ya da mikrokırık uygulanmasının yeterli olduğu kanaati hakimdir. ${ }^{[17,20-23]}$

\section{Yaş}

OKL'ye sahip hastanın yaşı önemli bir prognostik faktördür. Genç hastalarda prognoz daha iyidir. ${ }^{[24]}$

\section{Subkondral Kist ve Lezyonun Derinliği}

Subkondral kistin varlığı ve derinliğin fazlalığı, subkondral destekleyici ve besleyici kemiğin kaybı anlamına geldiği için, kötü prognoz göstergesidir. ${ }^{25,26]}$ Subkondral kisti olan hastalarda başarısız tedavi oranı \%53'tür. ${ }^{[27-29]}$

\section{Lezyonun Kondral ya da Osteokondral Olması}

Choi ve ark., 283 hastalık serilerinde, 52 aylık takip sonrası kondral lezyonlar ile osteokondral lezyonlarda subkondral kistler oluşmadığı sürece prognoz açısından fark olmadığını bildirmişlerdir. ${ }^{[30]}$

\section{Erken Yük Verme}

Bazı yazarlar, küçük lezyonlarda erken dönemde yük vermenin sonuca olumlu ya da olumsuz bir etkisinin olmadığını bildirmişlerdir. ${ }^{[31]}$ Gill ve ark. ise yaptıkları histolojik çalışmada, ameliyat sonrası erken dönemde yükten korumanın defekt dolma hızını belirgin olarak arttırdığını ve yeni kıkırdak dokusunun daha kaliteli oluştuğunu göstermişlerdir. ${ }^{[32]}$

\section{GÖRÜNTÜLEME YÖNTEMLERi}

\section{Direkt Grafi}

Geleneksel olarak, ayak bileği direkt grafileri ilk uygulanan görüntüleme yöntemleridir. Plantarfleksiyonda çekilen mortis grafisi posteromediyal lezyonların saptanmasını kolaylaştıııken, dorsifleksiyonda çekilen grafiler anterolateral ve anteromediyal lezyonların görüntülenmesini kolaylaştırır. ${ }^{[33]}$ Bu hastalarda direkt grafideki radyolojik bulgu, zor seçilmesine rağmen lezyonlu alanın radyolusen görülmesidir. Canale ve Belding, yaptıkları çalışmada oblik ve plantarfleksiyon grafilerinin, tibia ile üst üste gelmeyi engellemesi nedeniyle, standart grafilere oranla lezyonu daha belirgin gösterebildiğini vurgulamışlardır. Ancak farklı yöntemlere rağmen, direkt grafiler ile talus OKL'nin yarısından fazlası atlanmaktadır. ${ }^{[10]}$

\section{Manyetik Rezonans (MR) Görüntüleme}

MR, kemik iliği ödemini, yumuşak doku yaralanmalarını ve kıkırdak dokuyu gösterebildiği için OKL'de altın standart olan görüntüleme yöntemidir. ${ }^{[34,35]}$ Son yıllardaki görüntüleme teknolojisindeki gelişmeler sayesinde MR, normal kıkırdak, lezyonlu kıkırdak ve tedavi edilip fibrokıkırdak içeren kıkırdağı birbirinden ayırma kapasitesine sahiptir. ${ }^{[36]}$ T2-haritalamalı MR'nin kıkırdaktaki değişimi saptama duyarlılığı yüksektir. Ayrıca, kollojen fibrillerinin yüzey alanındaki dağılımının belirlenmesinde de önemli rol oynar. Böylece, kıkırdak yaralanmasındaki derinlik ve iyileşmesindeki takip daha iyi saptanabilir. ${ }^{[37,38]}$ Pek çok çalışma, T2 haritalamalı MR'nin tedavi edilmiş kıkırdak lezyonlarında kollajen fibrillerinin dağılımını saptayarak, oluşan kıkırdak dokunun nicelik olarak (hiyalin ve fibrin kıkırdak yapısı) gösterebildiğini bildirmektedir. ${ }^{[38]}$

\section{Bilgisayarlı Tomografi (BT)}

Kemik yapıyı belirgin olarak gösterebilen BT, Talus OKL lokasyonunun tayininde ve cerrahi öncesi olası 
malleolar osteotominin planlanması konusunda yardımcı olabilir. Ancak, kıkırdağın durumunun değerlendirilmesinde MR kadar kullanışlı değildir. ${ }^{[15,33]}$ Ameliyat öncesi ve sonrası dönemlerde kemikteki lezyonun boyutunun karşılaştırılmasında yarar sağlar. BT'nin aksiyel kesitleri, osteokondral lezyonun yerinin saptanması, boyutunun değerlendirilmesi ve talus OKL'nin doğru sınıflandırılmasında etkilidir. ${ }^{[6]}$

\section{TALUS OKL'DE SINIFLANDIRMA}

Talus OKL için en yaygın kullanılan sınıflandırma, Berndt ve Harty'nin 1959'da tanımladıkları ve osteokondral parçanın deplasman derecesine göre lezyonları evreleyen sınıflamadır. ${ }^{[3]}$ Dört evre tanımlanmıştır:

- Evre I: Küçük fokal subkondral çökme

- Evre II: Kısmi serbest parça (inkomplet kırık)

- Evre III: Deplase olmamış serbest parça (nondeplase komplet kırık)

- Evre IV: Deplase serbest parça (deplase komplet kırık)

2000 yılında Scranton ve McDermott, talus OKL'nin altındaki kemikte oluşan subkondral kisti içeren lezyonu tanımlayarak bu sınıflamaya eklemişlerdir ${ }^{25]}$ :

- Evre V: Subkondral kist

Mintz ve ark. talus OKL'nin artroskopik bulguları ile MR bulgularını kombine ederek bir sınıflandırma yapmışlardır. ${ }^{[37]}$ Altı evre tanımlanmıştır:

- Evre 0: Normal kıkırdak

- Evre 1: MR'de sinyal artışı ama artroskopide normal kıkırdak

- Evre 2: Kıkırdakta kemiğe ulaşmayan fibrillasyon ve çatlaklar

- Evre 3: Subkondral kemiği açığa çıkaran, kıkırdakta flep tarzında ayrışma

- Evre 4: Yer değiş̧irmemiş serbest parça

- Evre 5: Yer değiştirmiş serbest parça

\section{TALUS OKL TEDAVISi}

Tedavinin belirlenmesinde; lezyonun boyutu, lokasyonu, semptomların sıklığı ve şiddeti, hastanın günlük aktivite durumu göz önünde bulundurulmalıdır. Talus OKL'de tedavi semptomatik hastalarla sınırlı kalmalıdır. Semptom vermeyen hastaların, uygun süre aralıklarıyla lezyonun lokasyonu, boyutu ve sınıflandırılması sonrası klinik bulgular ve MR ile takip edilmesi yeterlidir. ${ }^{[39]}$ Asemptomatik ya da hafif semptomu olan çocuk hastalarda, bir süreliğine yük vermeden koruma ve aktivite modifikasyonu ile spontan iyileşme saptanabilmektedir. ${ }^{[33,40]}$ Ancak, yetişkin hastalarda spontan iyileşme söz konusu değildir. ${ }^{[39]}$

\section{Konservatif Tedavi}

Günlük aktif yaşam modifikasyonu, intraartiküler steroid ve PRP (trombositten zengin plazma) enjeksiyonları, yük vermeyi azaltma, breys ve ortez kullanımı ile fizik tedavi ve rehabilitasyon desteği, günümüzde tercih edilen konservatif tedavi yöntemleridir.[3,23] Ancak, konservatif tedavinin etkinliği talus OKL'de $\% 45$ 'in altındadır. ${ }^{[39]} \mathrm{Bu}$ tedaviler semptomatik tedavilerdir.

Tol ve ark.'nın 14 çalışmayı içeren derlemesinde, Berndt ve Hardy Evre I, Evre II lezyonlar ile mediyal yerleşimli Evre III lezyonlarda konservatif tedavinin başarısı, aktivite kısıtlaması ve istirahat ile \%59 olarak saptanmıştır. Aynı çalışmada, plastik alçı uygulanıp immobilize edilen hastalarda ise başarı \%41'de kalmıştır. Bu iki farklı konservatif tedavideki ortalama başarı oranı ise \%45 olarak bulunmuştur. Uygulanan bu tedavilerdeki süre ise üç hafta ile dört ay arasında farklılık göstermektedir. ${ }^{[41]}$ Canale ve Belding'e göre, konservatif tedavi Berndt ve Hardy sınıflamasına göre Evre I, Evre II ve mediyal yerleşimli Evre III lezyonlarla sınırlı kalmalıdır. ${ }^{[42]}$ Unutulmaması gereken önemli bir nokta ise lezyon boyutunun ve derinliğinin prognoza olan etkisidir. Lezyon boyutu büyüdükçe ve derinleştikçe, tedavideki başarı şansı azalmaktadır. ${ }^{[43]}$

PRP uygulaması yapılan hastalarda, sempotmatik tedavide ve artroz gelişimini yavaşlatmada etkin olduğunu gösteren çalışmalar vardır. ${ }^{[4,45]}$ Ancak, PRP'nin kıkırdaklar üzerinde etkinliğini gösteren daha geniş ve uzun sureli çalışmalara ihtiyaç duyulmaktadır.

\section{Cerrahi Tedavi}

Konservatif tedavi ile semptomları giderilemeyen, ayak bileği kronik instabilitesi eşlik eden, aktivite beklentisi fazla olan, Berndt ve Hardy sınıflamasına göre Evre III (mediyalde olmayan lezyonlar), Evre IV ve Evre $\checkmark$ hastalarda, cerrahi tedavi endikasyonu vardır. ${ }^{[43,46]}$

Kıkırdak onarımının tanımı, subkondral kemiğin ve artiküler yüzeyin uygulanan cerrahi işlemle oluşacak yeni kıkırdak doku ile restorasyonudur. Cerrahi tedavi ile, yeni oluşan kıkırdak dokusunun doğal kıkırdak gibi Tip II kollajen ve proteoglikan içeren hiyalin kıkırdağa benzer yapıda olması ve hastanın semptomlarını uzun süreli dindirmesi hedeflenmektedir. ${ }^{[40]}$

Talus OKL'ye uygulanan cerrahi tedavi prosedürleri altı farklı grupta incelenebilir ${ }^{[43,46,47]}$ :

1. Osteokondral parçanın redüksiyonu ve tespiti

2. Kemik iliği uyarımı 


\section{Artiküler kıkırdak replasmanı}

a. Otolog osteokondral transplantasyon (mozaikplasti)

b. Osteokondral allogreft transplantasyonu

4. Otolog kondrosit implantasyonu

5. Hücresiz çatı implantı (skaffold) uygulaması

6. Metal implantlar (yüzey artroplastisi)

\section{Osteokondral parçanın redüksiyonu ve tespiti}

Çoğunlukla ayak bileği inversiyon yaralanmaları sonrası, akut osteokondral kırıklar saptanabilir. Bu hastalarda acil cerrahi tedavi uygulanmalıdır. İşlem artroskopik de yapılabilir. Bu işlem için, küçük metal ya da emilebilir biyolojik vidalar kullanılabilir. Sonuçları yüz güldürücü olup, tespit edilemeyecek küçük parçaların rezeksiyonu tedavi için yeterlidir. ${ }^{[46]}$

\section{Kemik iliği uyarımı}

Talus OKL'de en sık kullanılan cerrahi yöntem, artroskopik mikrokırık veya drillemedir. Çünkü ucuzdur, kolaydır, komplikasyon oranı azdır ve ameliyat sonraSı ağrı diğer invaziv prosedürlere göre daha azdır. ${ }^{[48]}$ Genel yargı şudur ki, artroskopik mikrokırık işlemi $1,5 \mathrm{~cm}^{2}$ 'den küçük semptomatik lezyonlarda klinik olarak iyi sonuç verir. ${ }^{[33,49]}$ Chuckpaiwong ve ark., 1,5 cm'den küçük lezyonlarda uygulanan mikrokırık ile \%100 başarı sağlamışlardır. ${ }^{[7]}$ Choi ve ark., lezyon boyutu küçüldükçe sonuçların daha iyi olduğunu bildirmişler ve lezyon boyutu 0-99 $\mathrm{mm}^{2}$ olan hastaların sadece \%5,4'ünde AOFAS Ayak bileği-Ayak Önü Skala Skorunu 80'in altında saptamışlardır. ${ }^{50]}$

Mikrokırık veya drillemedeki hedef, subkondral kemikten mezenkimal kök hücrelerin eklem yüzeyine gelmesini sağlayıp fibrokıkırdak yeni bir kıkırdak yapımını uyarmaktır. Osteokondral parça prob ile muayenede saptandıktan sonra, çevre sağlam kıkırdağa kadar debridmanın yapılması gereklidir. ${ }^{[41]}$ Buraya mikrokırık bizi ya da awl ile açılacak deliklerle vaskülarize subkondral kemik fibrin tıkaç oluşturur ve sitokinler ile büyüme faktörleri salgılar. ${ }^{[51,52]}$ Defekt alanına gelen mezenkimal kök hücreler kondrosit-benzeri hücrelere dönüşerek yeni bir doku ve büyüme faktörlerinin etkisiyle Tip II kollajen oluşturur. ${ }^{[22,40,53,54]}$ Mikrokırık delikleri 3-4 mm aralıklarla ve her biri 3-4 mm derinlikte olmalıdır. ${ }^{[55]}$ Mikrokırık deliklerinin birleşmemesine özen gösterilmelidir; aksi takdirde burada oluşacak olan geniş kırık, kemik dansitesinde yoğunlaşmaya neden olur, yani sklerotik kemik oluşur. Bu da, subkondral kemikten kanamayı engeller. ${ }^{[56]}$ Ameliyat sonrası rehabilitasyonda 4-6 hafta yük vermekten kaçınılması ve fizik tedavi programına alınması gerekir. ${ }^{[57]}$
Artroskopik kemik iliği uyarımı, kısa ve orta dönem talus OKL'de etkili bir tedavi yöntemidir. Van Bueken ve ark., 26 aylık takipte, mikrokırık ve/veya abrazyon yaptıkları 15 talus OKL hastasında \%87 iyi ve mükemmel sonuç elde etmişlerdir. ${ }^{[58]}$ Becher ve ark.'nın çalışmasında ise, 5,2 yıl takibi yapılan orta dönem sonuçlarda, Hannover skorlamasına göre \%87 iyi ve mükemmel sonuç elde edilmiştir. ${ }^{[24]}$ Geniş derleme çalışmalarında da, erken ve orta dönem sonuçların ortalama \%85 iyi ve mükemmel sonuç verdiği, ancak geç dönemlerde kıkırdağa duyarı MR çalışmaları ile fibrillasyon ve çatlakların oluştuğu gösterilmiştir. ${ }^{[39,49]}$ Ferkel ve ark., 71 aylık takiplerde \%64-72 iyi ve mükemmel sonuç gösterirken, hastaların \%35'inde beş yıl önceki sonuçlara göre kötüleşme görülmüştür. ${ }^{[26]}$ Başka çalışmalarda da, kötü ya da yetersiz sonuç 66 aylık takipte \%54 ile \%47 arasında değişmektedir. Aynı çalışmalarda, hastaların \%45'i eski atletik seviyeye limitli dönmüş ya da dönememiştir. ${ }^{[27,57,59]}$ Kistik lezyon içeren $1 \mathrm{~cm}$ 'den büyük lezyonlarda ve revizyon işlemlerinde, mikrokırık ya da drilleme işlemi sonuçları kötüdür. ${ }^{[27,60]}$ Korunmasız talus omuz lezyonları da, diğer yerlerde yerleşim gösteren lezyonlara kıyasla daha kötü klinik sonuç vermektedir. ${ }^{[61]}$

\section{Artiküler kıkırdak replasmanı}

a. Otolog kondrosit implantasyonu (mozaikplasti): Dizin lateral kondilinden, yük almayan sahadan alınan subkondral kemik ve hiyalin kıkırdak içeren silindirik yapıdaki osteokondral greftlerin defekt sahasına press-fit olarak yerleştirilmesidir. Hiyalin kıkırdak içermesi, diğer tekniklerde oluşan fibrokıkırdağa oranla bir avantaj teşkil etmektedir. ${ }^{[43]}$ Mozaikplasti endikasyonları 1,5 $\mathrm{cm}^{2}$ 'den büyük lezyonlar, subkondral kist olan lezyonlar ve mikrokırıktan sonuç alınamamış olgulardır. Mediyal talar lezyonlarda mediyal malleol osteotomisi, lateral talar lezyonlarda ise fibular ya da tibial osteotomi, lezyon sahası yüzeyine greftlerin doğru yerleştirilebilmesi için gereklidir. ${ }^{[40,62]}$ Donör sahadan alınan greftler 6,8 ya da $10 \mathrm{~mm}$ kalınlığında olup, çoklu olarak yerleştirilebilir (Şekil 1). ${ }^{[40]} \mathrm{Bu}$ işlem sonrası hastanın yaklaşık 12 hafta yük vermesi engellenir, ancak eklem hareketine izin verilir. ${ }^{[63]}$

Mozaikplastinin erken ve orta dönem sonuçları, 8-12 mm boyuttaki lezyonlarda iyidir. Ayrıca, büyük ve kistik lezyonlarda da etkili bir tedavi yöntemidir. Nitekim 8-20 mm büyüklüğündeki kistik OKL'de, Scranton ve ark., ortalama 36 aylık takibi sonrası \%90 iyi ve mükemmel sonuç bildirmişlerdir. ${ }^{[25]}$ Benzer şekilde, Hangody ve ark. da 93 hasta serisinin 9,6 yıllık takibi sonrası \%92 iyi ve mükemmel sonuç bildirmişlerdir. ${ }^{[64]}$ iki yüz kırk üç hastalık 9 farklı çalışmanın değerlendirildiği 

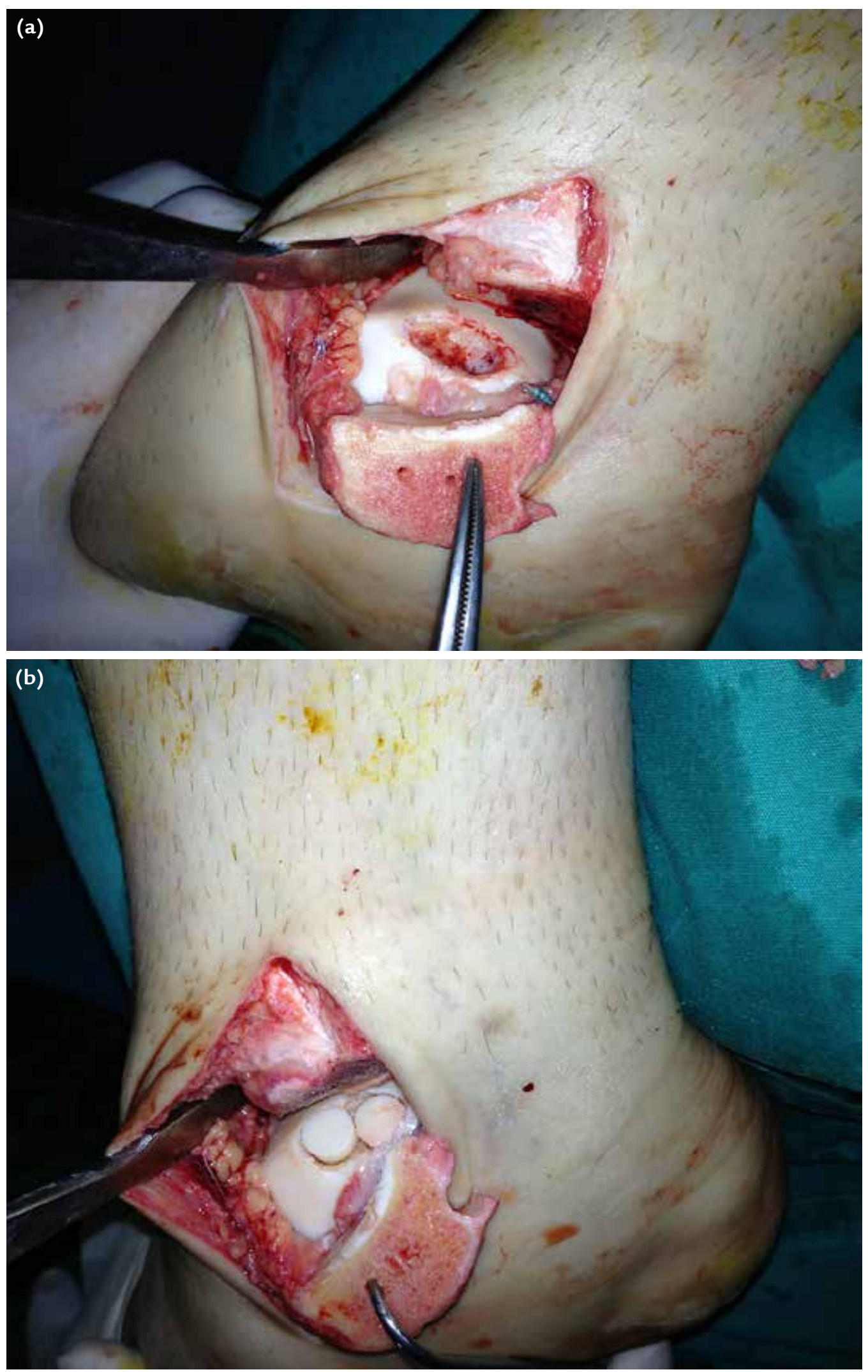

Şekil 1. Talus mediyal kubbedeki OKL (19 mm $\times 10 \mathrm{~mm}$ boyutunda). Mozaikplasti endikasyonu konulan hastaya mediyal malleol osteotomisi sonrası lezyon debride ediliyor (a). Aynı taraf dizden alınan iki adet $10 \mathrm{~mm}$ çapında silindirik osteokondral otogreftler defekt sahasına yerleştirilmiş (b). 
derlemede, Zengerink ve ark., iyi ve mükemmel sonucun mozaikplati uygulanan talus OKL olan hastalarda \%74 ile \%100 (ortalama \%87) arası olduğunu bildirmişlerdir. ${ }^{[49]}$. Kısa ve erken dönem sonuçlar açısından, özellikle $1,5 \mathrm{~cm}^{2}$ 'den büyük ve kistik lezyonlarda, otolog kondrosit implantasyonu mikrokırığa göre üstün bir tedavi yöntemidir. ${ }^{[43]}$ Donör saha morbiditesine bağIı ön diz ağrısı ve kemik iliği ödemi, görülebilen komplikasyonlardır. ${ }^{[0,64]}$ Ancak, en büyük handikapı $3 \mathrm{~cm}^{2}$ 'den büyük lezyonlarda osteokondral greft yetersizliği nedeniyle uygulanamamasıdır.

b. Osteokondral allogreft transplantasyonu: OKL'si $3 \mathrm{~cm}^{2}$ 'den büyük olan hastalarda, korunmasız talus omuz bölgesindeki lezyonlarda, mozaikplastinin yetersiz olacağı düşünülen kistik lezyonlarda, taze kadavradan temin edilecek osteokondral allogreft kullanım endikasyonu vardır. ${ }^{[46]}$ Soğuk zincirde tutulması belirgin kondrosit kaybına yol açacağı için (iki haftada \%20 -30 kayıp), transplantasyonun mümkün olduğu kadar erken dönemde yapılması gereklidir. İyi sonuçlara rağmen bazı çekinceler vardır: hastalık geçişi, immünolojik reaksiyon, ve greftin yatağa uyumsuzluğu. ${ }^{[46]}$

Bu prosedürün sonuçlarını açıklayacak bilimsel çalışmalar henüz çok sınırlıdır. Raikin ve ark., yaptıkları 15 hasta içeren ileriye dönük çalışmalarında ortalama 44 ay takipte bulunmuşlardır; $3 \mathrm{~cm}^{2}$ 'den büyük ya da kistik geniş lezyonlarda uyguladıkları osteokondral allogreft transplantasyonu sonrası hastaların ortalama AOFAS skoru ameliyat öncesi 38 iken ameliyat sonrası 83, VAS skoru ise ameliyat öncesi 8,5 iken ameliyat sonrası 3,3 olmuştur. Radyografik bulgularda ise; 10 hastada (\%67) kollaps ve rezorpsiyon, dokuz hastada (\%60) ise eklem aralığında daralma gözlenmiştir. Iki hastada (\%13) ayak bileği artrodezi gereksinimi duyulmuştur. ${ }^{[65]} \mathrm{EI}$ Rashidy ve ark.'nın 38 hastalık ve 37,7 aylık takipli çalışmasında, AOFAS Ayak bileği - Ayak önü skoru ameliyat öncesi 52 iken ameliyat sonrası 79 saptanmış, bir hastada greft rezorpsiyonu gelişmiştir. ${ }^{[66]}$ Yazarlardaki konsensus, osteokondral allogreft transplantasyonunun diğer tedavilerin uygulanamayacağı, büyük lezyonlar ya da diğer tedavilerden sonuç alınamamış hastalarda kurtarıcı tedavi olarak kullanılması gerektiğidir. ${ }^{46,47]}$

\section{Otolog kodrosit implantasyonu}

Britteberg tarafından 1994'te tanımlanan yöntemin en büyük avantajı, canlı kültürde üretilmiş kondrositlerin geniş defektif alana yerleştirilerek hiyalin-benzeri yeni kıkırdak oluşumunu sağlamasıdır, ancak bu iki seansta gerçekleştirilebilir. ${ }^{[67]}$ Birinci jenerasyon uygulamalarında periost ile dikilmiş defektif alanın içine hücrelerin enjeksiyonu ile yapılırken, ikinci jenerasyon uygulamalarında Tip I/III kollajen ya da hiyaluronik asit içeren matriks içinde üretilip defekt sahasına yerleştirilir ve fibrin ile tespit yapılır. Niemeyer ve ark.'nın 16 çalışmalık derlemelerinde, otolog kondrosit implantasyonu uygulanan hastalarda klinik başarı oranı \%89,9 saptanmıştır. ${ }^{68]}$ Giannini ve ark.'nın çalışmalarında 10 hastanın 10 yıllık geç dönem sonuçlarına göre, birinci jenerasyon otolog kondrosit implantasyonu uygulanan talus OKL'de AOFAS 37,9'dan 92,7'ye çıkarken MR'de entegrasyonun iyi olduğu saptanmıştır. ${ }^{[69]}$ Battaglia ve ark., 20 hastalık çalışmalarında, AOFAS skorunun beş yılda 59'dan 84'e çıktığını ve T2 haritalamalı MR görüntülerde defekt dolumunun \%69'unun doğala yakın kıkırdakla sağlandığını savunmuşlardır. ${ }^{[70]}$ Giannini ve ark.'nın ikinci jenerasyon otolog kondrosit implantasyonu ile ilgili 46 hastalı 36 ay takipli çalışmalarında, AOFAS 57,2'den 89,5'e çıkmıştır. Üç hastaya yapılan ikincil bakış artroskopisi sırasında ise, alınan kıkırdak biyopsisi sonucu hiyalin kıkırdağa benzer kıkırdak yapının oluştuğu gösterilmiştir. ${ }^{[71]}$ Bu prosedür sonrası spora dönüş oranı $\% 50$ olarak saptanmıştır. ${ }^{[72]}$

\section{Hücresiz çatı implantı (skaffold) uygulaması}

Mikrokırıkla elde edilen iyileşme potansiyelinin etkinliğini ve oluşan yeni kıkırdak dokunun kalitesini arttırmak için uygulanan yöntemdir. Mikrokırık ile yüzeye gelen mezenkimal kök hücrelerin eklem boşluğuna dağılmasını engelleyip yüzeyde tutunmasını sağlayan kollajen, hiyaluronik asit, Chitosan tarzı kıkırdak oluşumunu destekleyecek yapılar içeren farkIı tipteki matriksin defekt sahasına yerleştirilmesi ile gerçekleştirilir (Şekil 2). Bu skaffold kök hücrelerle beraber defekt yüzeyini doldurarak hiyalin benzeri kıkırdak oluşturmaktadır. ${ }^{[73]}$ Shimozona ve ark.'nın yaptığı 28 çalışmalık bir derlemede, 897 hastaya uygulanan hücresiz skaffold tedavisinde ortalama 37,7 aylık takip sonucu klinik AOFAS skorunda belirgin düzelmenin görüldüğü, $1,5 \mathrm{~cm}^{2}$ 'den daha büyük lezyonlarda da standart mikrokırıktan daha etklili olabileceği gösterilmiştir. ${ }^{[73]}$

\section{Metal implantlar (yüzey artroplatisi)}

Metalik yüzey protezlerinin defekt alanını doldurması ile gerçekleştirilen bu cerrahi prosedürde, teknik olarak yüzey kontürünü sağlamak amaçlanır. Metal implant, böylece ekleme gelen yükün dağılımını sağlar. Diğer tedavilerden sonuç alınamadığında ve revizyon olgularında tercih edilmesi uygun görülmektedir. ${ }^{[6]}$ 

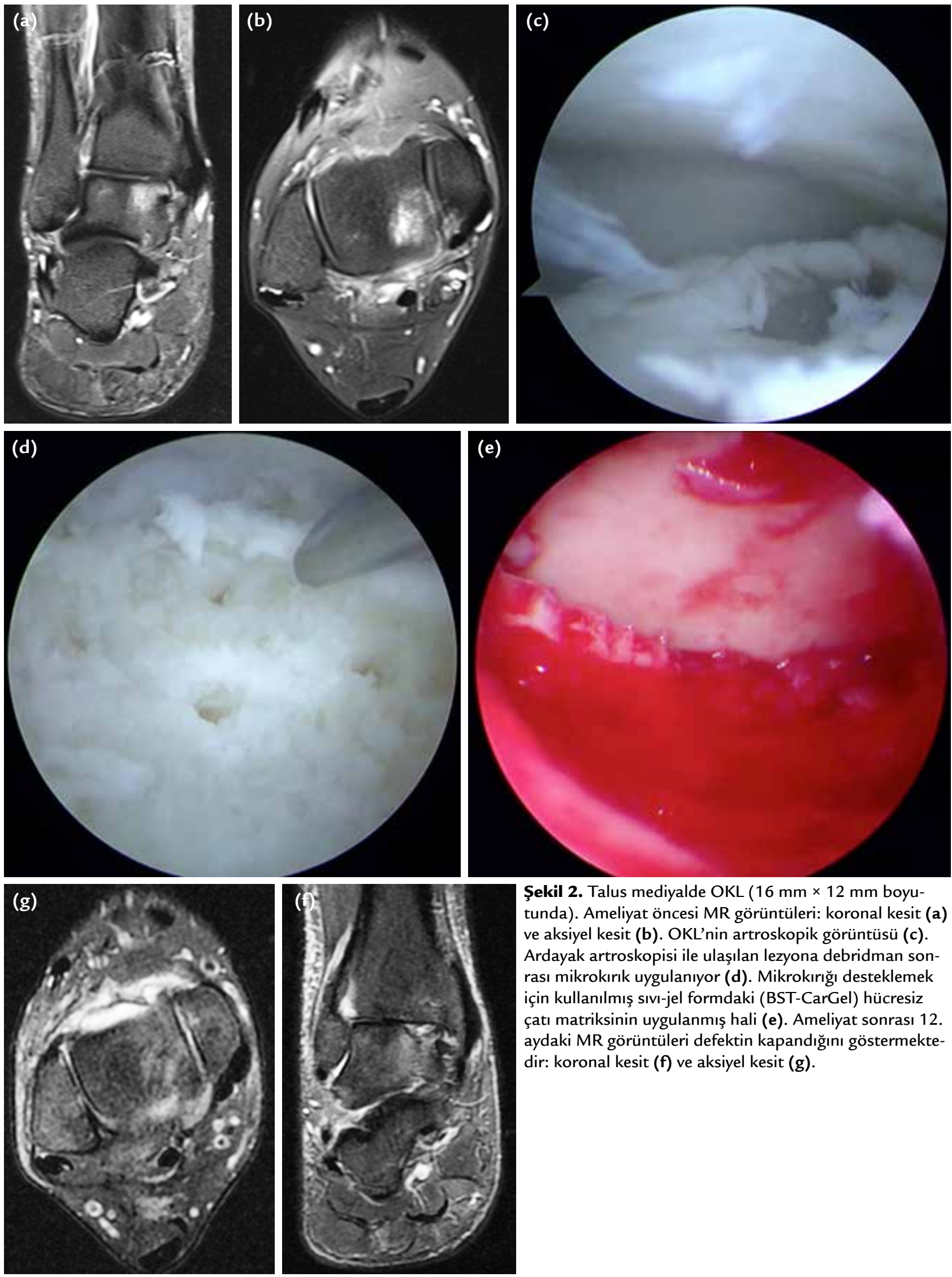

Şekil 2. Talus mediyalde OKL ( $16 \mathrm{~mm} \times 12 \mathrm{~mm}$ boyutunda). Ameliyat öncesi MR görüntüleri: koronal kesit (a) ve aksiyel kesit (b). OKL'nin artroskopik görüntüsü (c). Ardayak artroskopisi ile ulaşılan lezyona debridman sonrası mikrokırık uygulanıyor (d). Mikrokırığı desteklemek için kullanılmış sıvı-jel formdaki (BST-CarGel) hücresiz çatı matriksinin uygulanmış hali (e). Ameliyat sonrası 12. aydaki MR görüntüleri defektin kapandığını göstermektedir: koronal kesit (f) ve aksiyel kesit (g). 


\section{Talus OKL'de Biyolojik Destek Tedavileri}

Talus OKL'de uygulanan mikrokırık tedavisi sonrası, konsantre kemik iliği aspiratının iliak kanattan alınarak ekleme enjekte edildiği çalışmalar vardır. Mezenkimal kök hücre ve büyüme faktörü içerdiğinden, etkili olabileceği düşünülmüştür. ${ }^{[74]}$

Mikrokırık işlemi sonrası destek amacıyla hiyaluronik asit enjeksiyonu uygulamaları da yapılmaktadır. Sinoviyal sivida bulunan hiyaluronik asit in vitro ortamda kültürde bulunan kondrositlerin üremesini sağlamıştır. ${ }^{[75,76]}$

PRP, pek çok kıkırdak probleminde kullanılmaktadır. Amaç, ağrıyı azaltmak ve eklem fonksiyonu düzeltmektir. Taşıdığı büyüme hormonları ile iyileştirmeyi sağlayacağı düşünülmüştür. Anti-inflamatuvar etkisi de vardır. ${ }^{\text {[77] }}$

\section{Spora Dönüş}

Mikrokırık hastalarında spora dönüşün (15,1 hafta), mozaikplasti yapılan hastalara göre (19,6 hafta) daha çabuk olduğu, 46 hastalık çalışmada gösterilmiştir. ${ }^{[14]}$ Santral yerleşimli lezyonlarda (20,4 hafta) spora dönüş, anterolateral (14,4 hafta) ve anteromediyal lezyonlara (17,6 hafta) göre daha geçtir. ${ }^{[14]}$ Schuman ve ark.'nın yaptıkları 4,8 yıllık takipte, mikrokırık yapılan hastalarının \%82'sinde iyi ve mükemmel klinik sonuç alınmasına rağmen, hastaların \%45'i spora dönememiş ya da limitli dönebilmiştir. ${ }^{[78]}$ Paul ve ark. ise mozaikplasti uyguladıkları 131 hastalık çalışmalarında, spora dönen hastaların, özellikle de rekreatif spor yapan hastaların, aktivitelerinde modifikasyon yapma gereksinimi duyduklarını belirtmişlerdir. ${ }^{[79]}$ Valderabano ve ark., 72 aylık takip sonrası mozaikplasti uygulanan 12 hastanın \%33'ünün spora dönüş yapabildiğini yazmışlardır. ${ }^{[80]}$

\section{ÇIKARIMLAR}

Talus OKL için farklı tedavi prosedürleri uygulanmaktadır. Ancak tedavisi, lezyonun boyutu, yerleşimi, hastanın aktivite düzeyi ve hastanın semptomlarının şiddetine göre şekillendirilmektedir. Büyüklüğü 1,5 $\mathrm{cm}^{2}$ 'den fazla, kistik ve korunmasız talar omuz lezyonlarında prognoz kötü seyretmektedir. En sık uygulanan tedaviler, lezyonun boyutuna göre mikrokırık ve mozaikplastidir. Bunların yetersiz kaldığı durumlarda; otolog kondrosit implantasyonu, osteokondral allogreft transplantasyonu, hücresiz çatı skaffold uygulamaları kullanılmaktadır.

\section{KAYNAKLAR}

1. Baumhauer JF, Alosa DM, Renström AF, Trevino S, Beynnon $B$. A prospective study of ankle injury risk factors. Am J Sports Med 1995;23(5):564-70. Crossref

2. Alexander AH, Lichtman DM. Surgical treatment of transchondral talar-dome fractures (osteochondritis dissecans). Long-term follow-up. J Bone Joint Surg Am 1980;62(4):646-52.

3. Berndt AL, Harty M. Transchondral fractures (osteochondritis dissecans) of the talus. J Bone Joint Surg Am 1959;41-A:988-1020.

4. DeLee JC. Fractures and dislocations of the foot. In: Mann RA, Coughlin MJ, editors. Surgery of the Foot and Ankle, 6th ed. St Louis: Mosby-Year Book; 1993:1465-518.

5. Draper SD, Fallat LM. Autogenous bone grafting for the treatment of talar dome lesions. J Foot Ankle Surg 2000;39(1):15-23.

6. Ferkel RD. Arthroscopy of the ankle and foot. In: Mann RA, Coughlin MJ, editors. Surgery of the Foot and Ankle, 6th ed. St Louis: Mosby-Year Book; 1993:1277-312.

7. Mankin HJ. The response of articular cartilage to mechanical injury. J Bone Joint Surg Am 1982;64(3):460-6.

8. Jackson DW, Lalor PA, Aberman HM, Simon TM. Spontaneous repair of full thickness defects of articular cartilage in a goat model. A preliminary study. J Bone Joint Surg Am 2001;83-A(1):53-64.

9. Roden S, Tillegard P, Unanderscharin L. Osteochondritis dissecans and similar lesions of the talus: report of fifty-five cases with special reference to etiology and treatment. Acta Orthop Scand 1953;23(1):51-66.

10. Dragoni M, Bonasia DE, Amendola A. Osteochondral talar allograft for large osteochondral defects: technique tip. Foot Ankle Int 2011;32(9):910-6. Crossref

11. Chew KT, Tay E, Wong SE. Osteochondral lesions of the talus. Ann Acad Med Singapore 2008;37(1):63-88.

12. Loomer R, Fisher C, Lloyd-Smith R, Sisler J, Cooney T. Osteochondral lesions of the talus. Am J Sports Med 1993;21(1):13-9. Crossref

13. Laffernetre O. Osteochondral lesions of the talus: Current concept. Orthop Traumatol Surg Res 2010;96(5):554-66. Crossref

14. Saxena A, Eakin C. Articular talar injuries in athletes: results of microfracture and autogenous bone graft. Am J Sports Med 2007;35(10):1680-7. Crossref

15. Richardson DR. Ankle injuries. In: Canale ST, Beaty JH, editors. Campbell's Operative Orthopaedics, 11th ed. Philadelphia, PA. Mosby Elsevier; 2007. pp.2353-89.

16. Elias I, Zoga AC, Morrison WB, Besser MP, Schweitzer ME, Raikin SM. Osteochondral lesions of the talus: localization and morphologic data from 424 patients using a novel anatomical grid scheme. Foot Ankle Int 2007;28(2):154-61. Crossref

17. Chuckpaiwong B, Berkson EM, Theodore GH. Microfracture for osteochondral lesions of the ankle: outcome analysis and outcome predictors of 105 cases. Arthroscopy 2008;24(1):106-12. Crossref

18. Choi WJ, Choi GW, Kim JS, Lee JW. Prognostic significance of the containment and location of osteochondral lesions of the talus: independent adverse outcomes associated with uncontained lesions of the talar shoulder. Am J Sports Med 2013;41(1):126-33. Crossref 
19. Choi WJ, Park KK, Kim BS, Lee JW. Osteochondral lesion of the talus: is there a critical defect size for poor outcome? Am J Sports Med 2009;37(10):1974-80. Crossref

20. Christensen JC, Driscoll HL, Tencer AF. 1994 William J. Stickel Gold Award. Contact characteristics of the ankle joint. Part 2. The effects of talar dome cartilage defects. J Am Podiatr Med Assoc 1994;84(11):537-47. Crossref

21. Giannini S, Ceccarelli F, Girolami M, Coppola G, Ferrari A. Biological osteosynthesis in osteochondral lesions of the talus. Ital J Orthop Traumatol 1989;15(4):425-32.

22. Furukawa T, Eyre DR, Koide S, Glimcher MJ. Biochemical studies on repair cartilage resurfacing experimental defects in the rabbit knee. J Bone Joint Surg Am 1980;62(1):79-89.

23. Griffith JF, Lau DT, Yeung DK, Wong MW. High-resolution MR imaging of talar osteochondral lesions with new classification. Skeletal Radiol 2012;41(4):387-99. Crossref

24. Becher $\mathrm{C}$, Thermann $\mathrm{H}$. Results of microfracture in the treatment of articular cartilage defects of the talus. Foot Ankle Int 2005;26(8):583-9. Crossref

25. Scranton PE Jr, McDermott JE. Treatment of type $V$ osteochondral lesions of the talus with ipsilateral knee osteochondral autografts. Foot Ankle Int 2001;22(5):380-4. Crossref

26. Ferkel RD, Zanotti RM, Komenda GA, Sgaglione NA, Cheng MS, Applegate GR, Dopirak RM. Arthroscopic treatment of chronic osteochondral lesions of the talus: long-term results. Am J Sports Med 2008;36(9):1750-62. Crossref

27. Robinson DE, Winson IG, Harries WJ, Kelly AJ. Arthroscopic treatment of osteochondral lesions of the talus. J Bone Joint Surg Br 2003;85(7):989-93.

28. Han SH, Lee JW, Lee DY, Kang ES. Radiographic changes and clinical results of osteochondral defects of the talus with and without subchondral cysts. Foot Ankle Int 2006;27(12):110914. Crossref

29. Yoshimura I, Kanazawa K, Takeyama A, Angthong C, Ida T, Hagio T, Hanada H, Naito M. Arthroscopic bone marrow stimulation techniques for osteochondral lesions of the talus: prognostic factors for small lesions. Am J Sports Med 2013;41(3):528-34. Crossref

30. Choi GW, Choi WJ, Youn HK, Park YJ, Lee JW. Osteochondral lesions of the talus: are there any differences between osteochondral and chondral types? Am J Sports Med 2013;41(3):504-10. Crossref

31. Lee $D H$, Lee KB, Jung ST, Seon JK, Kim MS, Sung IH. Comparison of early versus delayed weightbearing outcomes after microfracture for small to midsized osteochondral lesions of the talus. Am J Sports Med 2012;40(9):2023-8. Crossref

32. Gill TJ, McCulloch PC, Glasson SS, Blanchet T, Morris EA. Chondral defect repair after the microfracture procedure: a nonhuman primate model. Am J Sports Med 2005;33(5):6805. Crossref

33. O'Loughlin PF, Heyworth BE, Kennedy JG. Current concepts in the diagnosis and treatment of osteochondral lesions of the ankle. Am J Sports Med 2010;38(2):392-404. Crossref

34. Schachter AK, Chen AL, Reddy PD, Tejwani NC. Osteochondral lesions of the talus. J Am Acad Orthop Surg 2005;13(3):152-8.

35. Spatt JF, Frank NG, Fox IM. Transchondral fractures of the dome of the talus. J Foot Surg 1986;25(1):68-72.

36. Potter HG, Chong le R, Sneag DB. Magnetic resonance imaging of cartilage repair. Sports Med Arthrosc 2008;16(4):236-45. Crossref
37. Mintz DN, Tashjian GS, Connell DA, Deland JT, O'Malley M, Potter HG. Osteochondral lesions of the talus: a new magnetic resonance grading system with arthroscopic correlation. Arthroscopy 2003;19(4):353-9. Crossref

38. Battaglia M, Rimondi E, Monti C, Guaraldi F, Sant'Andrea A, Buda R, Cavallo M, Giannini S, Vannini F. Validity of T2 mapping in characterization of the regeneration tissue by bone marrow derived cell transplantation in osteochondral lesions of the ankle. EurJ Radiol 2011;80(2):e132-9. Crossref

39. Easley ME, Latt LD, Santangelo JR, Merian-Genast M, Nunley JA 2nd. Osteochondral lesions of the talus. J Am Acad Orthop Surg 2010;18(10):616-30.

40. Murawski CD, Duke GL, DeyerTW, KennedyJG. Bone marrow aspirate concentrate (BMAC) as a biological adjunct to the surgical treatment of osteochondral lesions of the talus. Tech Foot Ankle Surg 2011;10(1):18-27. Crossref

41. Tol JL, Struijs PA, Bossuyt PM, Verhagen RA, van Dijk CN. Treatment strategies in osteochondral defects of the talar dome: a systematic review. Foot Ankle Int 2000;21(2):119-26.

42. Shearer C, Loomer R, Clement D. Nonoperatively managed stage 5 osteochondral talar lesions. Foot Ankle Int 2002;23(7):651-4. Crossref

43. Savage-Elliot I, Ross KA, Smyth NA, Murawski CD, Kennedy JG. Osteochondral lesions of the talus: current concepts review and evidence-based treatment paradigm. Foot Ankle Specialist 2014;7:5414-22. Crossref

44. Deol PP, Cuttica DJ, Smith WB, Berlet GC. Osteochondral lesions of the talus: size, age, and predictors of outcomes. Foot Ankle Clin 2013;18(1):13-34. Crossref

45. David TS, Shields CL. Radiofrequency and articular cartilage. Tech Knee Surg 2004;3(3):193-7.

46. Prado MP, Kennedy JG, Raduan F, Nery C. Diagnosis and treatment of osteochondral lesions of the ankle: current concepts. Rev Bras Ortop 2016;51(5):489-500. Crossref

47. Murawski CD, Kennedy JG. Operative treatment of osteochondral lesions of the talus. J Bone Joint Surg Am 2013;95(11):1045-54. Crossref

48. Emre TY, Ege T, Cift HT, Demircioğlu DT, Seyhan B, Uzun M. Open mosaicplasty in osteochondral lesions of the talus: a prospective study. J Foot Ankle Surg 2012;51(5):556-60. Crossref

49. Zengerink M, Struijs PA, Tol JL, van Dijk CN. Treatment of osteochondral lesions of the talus: a systematic review. Knee Surg Sports Traumatol Arthrosc 2010;18(2):238-46. Crossref

50. Choi WJ, Jo J, Lee JW. Osteochondral lesion of the talus: prognostic factors affecting the clinical outcome after arthroscopic marrow stimulation technique. Foot Ankle Clin 2013;18(1):67-78. Crossref

51. Buckwalter JA, Mow VC, Ratcliffe A. Restoration of Injured or Degenerated Articular Cartilage. J Am Acad Orthop Surg 1994;2(4):192-201.

52. DePalma AF, McKeever CD, Subin DK. Process of repair of articular cartilage demonstrated by histology and autoradiography with tritiated thymidine. Clin Orthop Relat Res 1966;48:229-42.

53. Cheung HS, Lynch KL, Johnson RP, Brewer BJ. In vitro synthesis of tissue specific type II collagen by healing cartilage. I. Shortterm repair of cartilage by mature rabbits. Arthritis Rheum 1980;23(2):211-9.

54. Hjertquist SO, Lemperg R. Histological, autoradiographic and microchemical studies of spontaneously healing osteochondral articular defects in adult rabbits. Calcif Tissue Res 1971;8(1):54-72. 
55. Steadman JR, Rodkey WG, Rodrigo JJ. Microfracture: surgical technique and rehabilitation to treat chondral defects. Clin Orthop Relat Res 2001;(391 Suppl):S362-9.

56. Chen $\mathrm{H}$, Sun J, Hoemann CD, Lascau-Coman V, Ouyang W, McKee MD, Shive MS, Buschmann MD. Drilling and microfracture lead to different bone structure and necrosis during bone-marrow stimulation for cartilage repair. J Orthop Res 2009;27(11):1432-8. Crossref

57. Murawski CD, Foo LF, Kennedy JG. A Review of Arthroscopic Bone Marrow Stimulation Techniques of the Talus: The Good, the Bad, and the Causes for Concern. Cartilage 2010;1(2):137-44. Crossref

58. Van Buecken K, Barrack RL, Alexander AH, ErtlJP. Arthroscopic treatment of transchondral talar dome fractures. Am J Sports Med 1989;17(3):350-6. Crossref

59. Hunt SA, Sherman O. Arthroscopic treatment of osteochondral lesions of the talus with correlation of outcome scoring systems. Arthroscopy 2003;19(4):360-7. Crossref

60. Robinson DE, Winson IG, Harries WJ, Kelly AJ. Arthroscopic treatment of osteochondral lesions of the talus. J Bone Joint Surg Br 2003;85(7):989-93.

61. Kolker D, Murray M, Wilson M. Osteochondral defects of the talus treated with autologous bone grafting. J Bone Joint Surg Br 2004;86(4):521-6.

62. Choi WJ, Kim BS, Lee JW. Osteochondral lesion of the talus: could age be an indication for arthroscopic treatment? Am J Sports Med 2012;40(2):419-24. Crossref

63. Kennedy JG, Murawski CD. The Treatment of Osteochondral Lesions of the Talus with Autologous Osteochondral Transplantation and Bone Marrow Aspirate Concentrate: Surgical Technique. Cartilage 2011;2(4):327-36. Crossref

64. Meehan RE, Brage ME. Fresh osteochondral allografting for osteochondral defects of the talus: a case review. Tech Foot Ankle Surg 2004;3(1):53-61.

65. Hangody L, Dobos J, Baló E, Pánics G, Hangody LR, Berkes I. Clinical experiences with autologous osteochondral mosaicplasty in an athletic population: a 17-year prospective multicenter study. Am J Sports Med 2010;38(6):1125-33. Crossref

66. Cuttica DJ, Smith WB, Hyer CF, Philbin TM, Berlet GC. Arthroscopic treatment of osteochondral lesions of the tibial plafond. Foot Ankle Int 2012;33(8):662-8. Crossref

67. Mologne TS, Ferkel RD. Arthroscopic treatment of osteochondral lesions of the distal tibia. Foot Ankle Int 2007;28(8):865-72. Crossref

68. Brittberg M, Lindahl A, Nilsson A, Ohlsson C, Isaksson O, Peterson L. Treatment of deep cartilage defects in the knee with autologous chondrocyte transplantation. N Engl J Med 1994;331(14):889-95. Crossref

69. Niemeyer P, Salzmann G, Schmal H, Mayr H, Südkamp NP. Autologous chondrocyte implantation for the treatment of chondral and osteochondral defects of the talus: a metaanalysis of available evidence. Knee Surg Sports Traumatol Arthrosc 2012;20(9):1696-703. Crossref
70. Giannini S, Buda R, Grigolo B, Vannini F. Autologous chondrocyte transplantation in osteochondral lesions of the ankle joint. Foot Ankle Int 2001;22(6):513-7.

71. Battaglia M, Vannini F, Buda R, Cavallo M, Ruffilli A, Monti C, Galletti S, Giannini S. Arthroscopic autologous chondrocyte implantation in osteochondral lesions of the talus: mid-term T2-mapping MRI evaluation. Knee Surg Sports Traumatol Arthrosc 2011;19(8):1376-84. Crossref

72. Giannini S, Buda R, Vannini F, Di Caprio F, Grigolo B. Arthroscopic autologous chondrocyte implantation in osteochondral lesions of the talus: surgical technique and results. Am J Sports Med 2008;36(5):873-80. Crossref

73. Magnan B, Samaila E, Bondi M, Vecchini E, Micheloni GM, Bartolozzi P. Three-dimensional matrix-induced autologous chondrocytes implantation for osteochondral lesions of the talus: midterm results. Adv Orthop 2012;2012:942174. Crossref

74. Shimozono Y, Yasui Y, Ross AW, Miyamoto W, Kennedy JG. Scaffolds based therapy for osteochondral lesions of the talus: A systematic review. World J Orthop 2017;8(10):798808. Crossref

75. Payne KA, Didiano DM, Chu CR. Donor sex and age influence the chondrogenic potential of human femoral bone marrow stem cells. Osteoarthritis Cartilage 2010;18(5):705-13. Crossref

76. Doral MN, Bilge O, Batmaz G, Donmez G, Turhan E, Demirel M, Atay OA, Uzumcugil A, Atesok K, Kaya D. Treatment of osteochondral lesions of the talus with microfracture technique and postoperative hyaluronan injection. Knee Surg Sports Traumatol Arthrosc 2012;20(7):1398-403. Crossref

77. Kawasaki K, Ochi M, Uchio Y, Adachi N, Matsusaki M. Hyaluronic acid enhances proliferation and chondroitin sulfate synthesis in cultured chondrocytes embedded in collagen gels. J Cell Physiol 1999;179(2):142-8. Crossref

78. Krüger JP, Hondke S, Endres M, Pruss A, Siclari A, Kaps C. Human platelet-rich plasma stimulates migration and chondrogenic differentiation of human subchondral progenitor cells. J Orthop Res 2012;30(6):845-52. Crossref

79. Schuman L, Struijs PA, van Dijk CN. Arthroscopic treatment for osteochondral defects of the talus: results at follow-up at 2 to 11 years. J Bone Joint Surg Br 2002;84(3):364-8.

80. Paul J, Sagstetter M, Lämmle L, Spang J, El-Azab H, Imhoff $A B$, Hinterwimmer S. Sports activity after osteochondral transplantation of the talus. Am J Sports Med 2012;40(4):870-4. Crossref

81. Valderrabano V, Leumann A, Rasch H, EgelhofT, Hintermann $B$, Pagenstert G. Knee-to-ankle mosaicplasty for the treatment of osteochondral lesions of the ankle joint. Am J Sports Med 2009;37 Suppl 1:105S-11S. Crossref 